\title{
8 Family firms and corporate responsibility in peripheral regions
}

\author{
Martin Graffenberger and Franziska Görmar
}

\section{Introduction}

Research on family firms has traditionally focused on the analytical distinction between them and non-family firms, implying, amongst others, differences in terms of demographic, structural, and behavioural dimensions (Basco, 2015). While family firms, like any economic agent, pursue pecuniary goals, non-financial goals are important aspects of their strategic agendas (Aparicio, Basco, Iturralde, \& Maseda, 2017). Specifically, long term orientation of strategic decisions (Bird \& Wennberg, 2014; Zellweger, Chrisman, Chua, \& Steier, 2019), responsibility for employees and communities (Campopiano, De Massis, \& Chirico, 2014; Gallo, 2004), and sensibility towards aspects of social status and reputation (Chrisman, Chua, Pearson, \& Barnett, 2012) appear as distinct attributes of family firms' business practices to mediate economic and non-economic goals.

The aforementioned attributes help explain why family firms exhibit high degrees of local embeddedness (Baù, Block, Cruz, \& Naldi, 2017; Stough et al., 2015). Embeddedness creates linkages between firms and their diverse contexts and, thereby, functions as an essential lever to facilitate and channel regional development dynamics regarding both economic and noneconomic aspects (Pike, Langendijk, \& Vale, 2000). Given that around 90\% of businesses in Germany are family firms, accounting for $58 \%$ of private employment and $52 \%$ of aggregate turnover, and that many of them are of considerable size (Stiftung Familienunternehmen, 2019), family firms are a crucial determinant of regional development processes (Basco, 2015). However, there is a lack of research on interpreting and understanding the role they play in local economic and social development (Baù et al., 2017; Lengauer \& Tödtling, 2010). Because the nexus between family and regions still requires further research (Basco, 2015; Stough et al., 2015), we aim at offering insights on wider community-related and societal implications by considering regional engagement and philanthropic activities through the lens of corporate local and regional responsibility (CLRR). That is, we attempt to shed new light on the following research question: How and why do firms take responsibility for their local communities? 
The empirical material, gathered as part of a wider research project, relates to the so-called "Hidden Champions" located in small towns in peripheral regions in Germany. Hidden Champions, firms that are market leaders in specific product segments, are regarded a suitable example to study corporate responsibility as they typically possess sufficient resources for engagement, tend to exhibit a high degree of local embeddedness, and are mostly family controlled (Vonnahme, Graffenberger, Görmar, \& Lang, 2018). There are three main stylised facts that guide our focus on firms located in small towns in peripheral regions. First, small towns are a central part of the German settlement system but face particular development challenges. Second, research has neglected to focus the attention on them (Academy for Spatial Research and Planning, 2019; Bell \& Jayne, 2009). Finally, in the German context, successful and innovative firms are frequently located in small towns.

In this chapter, we examine three companies located in two peripheral small towns in Germany - Bad Berleburg in North Rhine-Westphalia (headquarters of two family-owned Hidden Champions) and Schierling in Bavaria (headquarters of one management-led Hidden Champion). We selected the cases based on company specifications such as firm size and (changes in) the nature of firm ownership as well as the location and size of the towns where they dwell. Furthermore, the selected case firms reflect variance regarding their ownership structures, by recognising both long-lasting family ownership and the transition from family to non-family ownership with subsequent integration into an international family holding.

We find that successful and locally embedded companies are generally willing to provide substantial resources for community purposes, in particular regarding local/regional cultural, social, and educational matters. Engagement is coupled with diverse firm interests such as securing human resources by maintaining and increasing the attractiveness of place and region. Hence, these activities can have pronounced effects on small-town development, especially as the spatial focus of engagement is mainly on the immediate firm environment. The actions of locally embedded companies constitute a substantial supplement to the activities and investments of municipal and civil society actors and, thereby, open room to manoeuvre and to shape local and regional structures. All selected firms, regardless of their ownership nature and structures, are engaged in corporate giving and corporate volunteering activities.

However, our findings indicate that ownership structures may affect both scope and intensity of community engagement. Family firms are particularly involved in comprehensive and strategic activities, such as steering group membership of local initiatives or participation in municipal strategy processes. This comprehensive engagement is driven by a sense of obligation and is coupled with efforts to generate returns for the local community i.e., beyond mere economic returns. Since the firms' decision-makers grew up and still live locally, socio-emotional place attachment emerges as a distinct driver of firm engagement. Consequently, our study allows the 
further differentiation of previous findings on the interrelations between firm engagement and ownership structures (e.g., Bürcher, 2017; Lengauer \& Tödtling, 2010). We observe that while family involvement seems to affect the tendency of a firm to engage in corporate support activities (long-term orientation), sponsoring and volunteering activities are common in any firm regardless of its ownership structure.

\section{Theoretical framework}

\section{Family firms and embeddedness}

Regional embeddedness is about the involvement of (economic) actors in a geographically bounded social structure (Granovetter, 1973; Hess, 2004) whereby these actors become tied to spatial contexts (Pike et al., 2000). Through embeddedness, these actors shape the economic as well as societal dynamics of places and regions (Hess, 2004). Hence, embeddedness reflects the firm-place nexus and constitutes an integral part of local and regional development beyond its economic dimension (Bürcher, 2017). In economic terms, embeddedness relates not only to transactions with regional suppliers, sub-contractors, and customers; integration in regional networks and intra-regional competition but also access to technology, human resources, and regionally specific knowledge (Clifton, Gärtner, \& Rehfeld, 2011; Lengauer \& Tödtling, 2010). In social and cultural terms, embeddedness surfaces in linkages to local/regional administrative, intermediate, and civil society stakeholders (Baù et al., 2019; Bird \& Wennberg, 2014; Bürcher, 2017) and a firm's integration into regional cultures, manifested in collective values, norms, and symbols (Clifton et al., 2011; Dequech, 2003). Thus, embeddedness facilitates the mobilisation of local resources, trust, and networks. Consequently, embeddedness operates as a determinant for corporate and regional competitiveness (Baù et al., 2019) but also conditions firms' intentions to pursue non-financial goals, such as philanthropy and community engagement activities (Bürcher 2017; Campopiano et al., 2014; Lengauer \& Tödtling, 2010).

However, not all economic actors are similarly linked with their local communities. For instance, it has been mentioned that, compared to their non-family counterparts, family firms exhibit profound degrees of local embeddedness (Basco, 2015; Baù et al., 2017; Bird \& Wennberg, 2014), especially regarding non-economic and social dimensions (Chrisman et al., 2012; Zellweger et al., 2019). Family reputation (Deephouse \& Jaskiewicz, 2013), the fact that decision-makers typically grew up and live locally, shared regional mindsets (Dörhöfer, Minnig, Pekruhl, \& Prud'homme van Reine, 2011), and family members being integrated into the community's everyday life (Lang, Görmar, Graffenberger, \& Vonnahme, 2019) also play a decisive role in their engagement. Family firms are well embedded locally and benefit from this (Baù et al., 2019), especially in rural regions, where they "have the possibility to form alliances and build close connections with the 
community and are exposed less to the anonymity of urban areas" (Bird \& Wennberg, 2014, 425).

It is important to note that embeddedness is not a static manifestation but an inherently dynamic concept (Hess, 2004). In this sense, Pike et al. (2000) highlight the importance of considering spatial processes of embedding rather than a state of embeddedness as well as counter-processes of disembedding. Thus, a firm's level of embeddedness might increase or decrease over time, as the characteristics of their ties to local/regional contexts alter for reasons such as changes in purchasing strategy, management, or ownership structure. In this sense, a firm's relation to economic actors, as well as administrative and societal stakeholders, fluctuates (Zellweger et al., 2019).

\section{Corporate local and regional responsibility}

The "active involvement of firms in shaping the contexts and networks a firm is involved in" (Lengauer \& Tödtling, 2010, 7) is widely understood as a key element of corporate engagement. It is a distinct form of and mechanism to strengthen socio-spatial embeddedness (Bürcher, 2017). Consequently, and due to their typically pronounced degree of local embeddedness, family firms are particularly receptive to corporate engagement (Campopiano et al., 2014) through their locally embedded decision-takers.

Research on corporate engagement lacks both distinct spatial elements (Lengauer \& Tödtling, 2010) and ownership-related considerations (Campopiano et al., 2014). Even though activities under the umbrella of concepts like corporate social responsibility or corporate citizenship often have a (more or less explicit) regional orientation, the concepts themselves are non-spatial. To incorporate spatial considerations, this chapter adopts the notion of CLRR developed by Hohn, Kleine-König, and Schiek (2014). Departing from a holistic understanding, CLRR is about the "development partnership between companies and the region" (Kiese \& Schiek, 2016, 10) in which firms engage voluntarily for economic, ecological, social, and cultural matters.

The associated activities in the partnerships related to CLRR can be categorised into three distinct, yet not mutually exclusive, mechanisms: corporate giving, corporate volunteering, and corporate support (Hohn et al., 2014; Vilain, 2010). Corporate giving refers to engagement through occasional or long-term financial and material donations. It emerges, for instance, as sponsoring of cultural and social events, institutions, associations, and sports clubs but also material support for (vocational; music) schools and kindergartens. Secondly, activities along the lines of corporate volunteering involve, for instance, leaves of absence for staff to participate in local fire brigades and social activities or days with schools and educational institutions. Furthermore, firms frequently provide their premises as venues for cultural events, such as concerts or readings. Finally, corporate support refers to strategic, i.e. rather formalised, and long-term engagement in local and regional development processes - e.g., through support of and 
participation in civic or regional management initiatives, local strategy formation, or the establishment of foundations. CLRR considers engagement primarily in the direct context of a firm's location. Consequently, corresponding activities can contribute directly and indirectly to various dimensions of small-town development - e.g., by securing diverse and high-quality social and cultural landscapes.

Generally speaking, proactivity, strategic (business) orientation, commitment, and resource input tend to increase from giving to support activities (Bürcher, 2017; Kiese \& Schiek, 2016). Even if CLRR activities typically exceed immediate business goals, they might be coupled with and partially motivated by business-oriented considerations (Kiese \& Schiek, 2016). For instance, local engagement can increase visibility and reputation of firms. Additionally, it has been highlighted that corporate responsibility can be seen as a specific instrument to shape socio-spatial contexts and to maintain favourable local and regional living and business conditions - which might be particularly relevant for firms located in peripheral regions (Bird \& Wennberg, 2014; Bürcher, 2017) but also result in elevated expectations regarding the engagement of (internationally successful family) firms. While firm engagement can support processes of local and regional development, associated activities are, due to their voluntary nature, highly volatile, dependent on firm success, and likely to be cut in economic downturns (Gallo 2004; Lengauer \& Tödtling, 2010), such as the current COVID-19 crisis.

Research has so far largely neglected the particular effects of family firms in peripheral regions (Bird \& Wennberg, 2014) and especially their wider societal implications (Zellweger et al., 2019). Hence, this study specifically focusses on how firms located in peripheral regions engage in processes of (small) town development and, thereby, highlights a particular spatial dimension within the debate on corporate responsibility. With this chapter, we establish a direct link between CLRR and firms' immediate operational contexts, but also adopt its holistic understanding by investigating the linkages between CLRR and cooperative small-town development (Deutscher Städtetag, 2013).

\section{Consciousness and strategy: firms as actors in small-town development}

\section{Case studies - local contexts and firm embeddedness}

We investigate three case studies of Hidden Champion firms located in small towns in peripheral regions in Germany, namely EJOT and Berleburger Schaumstoffwerke (BSW) located in Bad Berleburg (North RhineWestphalia) and Holmer Maschinenbau located in Schierling (Bavaria). The case studies draw on 13 interviews conducted with firm representatives (owners, management), central administrative (mayors, administrative staff), and civil society actors (representatives of local clubs, associations and initiatives, regional management, etc.), as well as local media, during 
multi-day field visits in 2018. Interview material was complemented with data gathered through desk research (from municipal documents, company websites, media etc.).

All three firms are important employers in their towns and contribute, with their economic interrelations and linkages, considerably to local and regional development. Hence, in all cases the economic core activities (through employment, taxes, purchasing power, expansion, etc.) are considered their main pecuniary contribution to local development. In the following section, we briefly portray the companies and give a short insight into their respective local contexts.

EJOT and BSW firms are both family-owned and in the third generation of family ownership. EJOT, founded in 1922 by the great uncle of today's managing director, currently employs more than 3,000 persons, approximately 1,300 of whom work in Bad Berleburg and its surroundings. The main goods produced by the company are special screws and other connecting elements. BSW was founded in 1954 and employs about 650 persons, of which 470 work in Bad Berleburg. The main product of BSW is foam material utilised for sports mats or running tracks (Box 8.1).

\section{BOX 8.1: CONTEXT INFORMATION ON BAD BERLEBURG}

Bad Berleburg, North Rhine-Westphalia

- Regional centre in the Siegen-Wittgenstein county

- Peripheral location

- Inhabitants (2018): 19,515; rather stable dynamics

- Local employment (2018): 7,951; positive dynamics

- Focus on industrial production and the health sector; spa town

Bad Berleburg faces ongoing demographic challenges that manifest in selective out-migration and population ageing. Both trends are of significance to local firms, in regards to their needs for qualified workforce. Infrastructural access, both road and railway, are deemed highly problematic, resulting in the local "Route 57" lobbying initiative.

In the past, the municipality experienced a difficult financial situation. However, the city council re-oriented its urban planning and development strategy, deliberately involving economic and civil society stakeholders in strategy formation processes and project activities.

In the past, the healthcare sector was highly important for Bad Berleburg but has, due to regulatory changes and economic restructuring, somewhat lost significance. Currently, Bad Berleburg builds on a diversified industrial base characterised by medium-sized and family-owned companies - including the Hidden Champions EJOT and Berleburger Schaumstoffwerke (BSW). 
Both firms are highly embedded in Bad Berleburg in economic as well as social and cultural terms. Economically, they constitute a great share of local employment and significantly contribute to local tax revenue and purchasing power. Additionally, they strengthen the local economy through subcontracts and the concentration of their economic activities within the region. Committing themselves to Bad Berleburg as their headquarters' location, both firms have expanded in recent years, partly by reusing former buildings of the healthcare industries and industrial brownfields. Both companies have their headquarter buildings in central locations, reflecting economic relevance and importance for the urban landscape.

In social and cultural terms, Bad Berleburg is not only the headquarters of the firms but also residential place of the founding families, who grew up in this region and are engaged privately in various local associations and initiatives. The same applies to their employees, who originate mainly from the surroundings. Both firms show strong loyalty towards their employees and are themselves engaged in multiple ways in the town's societal life. Thus, it can be expected that traditions and regional values are shared by both managers and employees (Dörhöfer et al., 2011), resulting in strong regional ties. Both firms understand themselves as rooted in and interwoven with the region where they find appropriate workforce and human resources to successfully manage their corporate development.

Human resources are a great potential and capital of our company and that certainly ties us to this location. It is certainly not the local infrastructure, which is a real disadvantage.

(Interview BSW, August 8, 2018)

As a consequence, the two firms' leaders are very much motivated "to keep the town and the region attractive for employees" (Interview EJOT, August 08, 2018) and engage in its development.

The Hidden Champion Holmer was founded in 1969 and produces sugarbeet harvesters and other agricultural machines. Of the firm's 420 employees, 330 work in Schierling. Holmer has witnessed several changes in the ownership structure. In 2004, the founder Alfons Holmer sold the enterprise to a private equity company, which in turn sold it to a second private equity company in 2006. Since 2013, Holmer has belonged to the French family-owned holding Exel Industries, who are familiar with the agricultural machinery business. Hence, Holmer can be considered a management-led enterprise with a family-owned enterprise in the background (Box 8.2).

Both the municipality and the company management consider the private equity ownership phase marked by uncertainty and turbulence. Since the acquisition of the company by Exel Industries, the relations between the town administration and the company improved considerably, strengthening, once more, the base for communication and trust. 
Ten years in private equity were certainly not favourable for our company, particularly because the identity was missing. [...] It was a difficult period. Finally, in 2013 we could indirectly get back into family ownership.

(Interview Holmer, November 6, 2018)

By acquiring a property of 14 hectares in a newly established industrial area, Holmer committed itself to the location of Schierling, which was a long-term and strategic decision by the management.

The development of the new location was a long-term and strategic decision, knowing that we are not able to relocate anywhere else. This is just not possible due to our product and our self-image. Our knowledge carriers are located here and we are deeply rooted. Therefore, we do not want to leave.

(Interview Holmer, November 6, 2018)

\section{BOX 8.2: CONTEXT INFORMATION ON SCHIERLING}

Schierling, Bavaria

- Medium centre in the Regensburg county

- Peripheral location

- Inhabitants (2018): 8,208; positive dynamics

- $\quad$ Local employment (2018): 3,013; positive dynamics

- Focus on industrial production; commercial location

Schierling has continuously gained population in the past few years. These population dynamics are partly due to its location in the commuting area of Regensburg. Schierling is well connected in terms of infrastructure. Recent infrastructural improvements have also facilitated the development of a commercial industrial site, which attracted a major automotive supplier and led to several local/regional firms, such as the Hidden Champion Holmer Maschinenbau GmbH, expanding their operations.

Due to these recent dynamics, the financial situation of Schierling is rather positive. Beginning in 1999, a number of urban development concepts were elaborated and implemented, resulting, for instance, in the establishment of a centrally located service centre containing local supplies, a medical centre, and the public library as well as space for meetings. Currently, a major project of the city council is the development of a new hotel. 
Regarding its regional embeddedness, the economic aspects are clearly considered most important. The company is one of the biggest employers in the region and is an important partner in education. This generates purchasing power in the region and has increased tax revenue for the municipality, opening up considerable room for manoeuvring urban development.

As far as possible, Holmer organises its supply chains regionally, thereby strengthening local and regional economic structures. Further, the commitment of Holmer to stay in Schierling has substantially influenced the development of the municipality. A new commercial estate was developed as result of Holmer's expansion plans, a process which was characterised by continuous communication between the city council and the firm. Both sides emphasise that the size of the town may also have a facilitating influence on their mutual communication.

Socially and culturally, the enterprise is apparently less embedded than other companies in Bad Berleburg. While a major share of the employees originate from the region and are active in local associations like the fire brigade, the persons responsible for the management mostly live in Regensburg, a nearby regional centre. This fact might explain the supportive but rather distant and professional relations between firm and community actors in Schierling. Although there are many well-functioning communication channels, formal and informal, between the municipality and the firm, both sides have precise ideas about the competencies and responsibilities of public and private actors in urban development processes, which are rather separated from each other.

\section{Corporate responsibility: from club sponsoring to community building(s)}

All Hidden Champions investigated as part of this research exhibit distinct interests in assisting the development of their immediate (headquarters) environments. Consequently, they engage in various, wide-ranging activities, particularly regarding cultural and social initiatives, as well as education, environmental concerns, and sports. Activities along the lines of CLRR and their different mechanisms (corporate giving, volunteering, and support) were identified in each of the selected cases, albeit with different levels of engagement.

All three companies provide financial and material support for a wide range of local initiatives and institutions - e.g., for cultural associations and events, a biodiversity project on wisents, sports clubs (e.g., football, athletics and biathlon), schools/kindergartens, and youth associations. Additionally, BSW and EJOT open their facilities as venues for events such as concerts or literary readings. At Holmer, employees can propose relevant projects and initiatives to the management for funding and even use the facilities and machinery of the firm for their own civic engagement. Generally, it can 
be observed that, through these corporate giving and volunteering activities, the companies aim at making a conscious contribution to the overall locational attractiveness of their headquarter sites. In this sense, a certain diversity and quality of local social and cultural landscapes are considered relevant locational factors when it comes to binding and attracting workforce (Table 8.1):

We [think about engagement] every time we have the impression that some of our employees may benefit.

(Interview EJOT, August 8, 2018)

Table 8.1 Selected CLRR activities of case firms

\begin{tabular}{|c|c|c|c|}
\hline & Corporate giving & $\begin{array}{l}\text { Corporate } \\
\text { volunteering }\end{array}$ & Corporate support \\
\hline EJOT & $\begin{array}{l}\text { Financial/material } \\
\text { support of clubs and } \\
\text { schools } \\
\text { Biodiversity project on } \\
\text { wisents } \\
\text { Financial support of } \\
\text { community centre }\end{array}$ & $\begin{array}{l}\text { Leaves of absence } \\
\text { for staff } \\
\text { Project activities } \\
\text { with schools } \\
\text { Provision of rooms } \\
\text { for local events }\end{array}$ & $\begin{array}{l}\text { Steering group } \\
\text { membership, e.g., } \\
\text { vocational training } \\
\text { centre, regional } \\
\text { management } \\
\text { (LEADER), Route } \\
57 \\
\text { Participation in } \\
\text { municipal projects } \\
\text { and strategy } \\
\text { formation } \\
\text { Ideational and } \\
\text { planning support of } \\
\text { community centre }\end{array}$ \\
\hline BSW & $\begin{array}{l}\text { Sponsoring of local } \\
\text { events, clubs and } \\
\text { initiatives } \\
\text { Project-based material } \\
\text { donations, e.g., } \\
\text { playgrounds } \\
\text { Financial support of } \\
\text { community centre }\end{array}$ & $\begin{array}{l}\text { Leaves of absence } \\
\text { for staff } \\
\text { Cooperation with } \\
\text { vocational schools } \\
\text { Provision of rooms } \\
\text { for local events }\end{array}$ & $\begin{array}{l}\text { Steering group } \\
\text { membership of } \\
\text { vocational training } \\
\text { centre } \\
\text { Participation in } \\
\text { municipal projects } \\
\text { and strategy } \\
\text { formation } \\
\text { Ideational and } \\
\text { planning support of } \\
\text { community centre }\end{array}$ \\
\hline Holmer & $\begin{array}{l}\text { Selective and request- } \\
\text { based sponsoring } \\
\text { of local clubs and } \\
\text { initiatives } \\
\text { Financial/material } \\
\text { support of } \\
\text { kindergartens }\end{array}$ & $\begin{array}{l}\text { Leaves of absence } \\
\text { for staff } \\
\text { Project activities } \\
\text { with local school } \\
\text { Membership in } \\
\text { municipal climate } \\
\text { change panel }\end{array}$ & \\
\hline
\end{tabular}


In addition to financial and material support, all companies grant leaves of absence for employees to participate in fire brigades and the Red Cross, for example. Furthermore, they cooperate closely with local/regional schools and vocational training centres, organise internships or open days to present themselves to future members of the workforce, and even enter into formal partnerships with neighbouring schools. A very important aspect in this regard is the high value that they place on training and apprenticeship. EJOT and BSW, for example, are strongly involved in the regional structures for professional education, being part of a regional educational centre (Bildungszentrum Wittgenstein $\mathrm{GmbH}$ ) as founding and currently managing members.

Regarding strategically oriented corporate support processes, the intensity of engagement differs between the three companies. Both EJOT and BSW have been actively involved in strategic local and regional planning processes such as the municipal mission process ("Leitbildprozess"). However, the managing directors referred to their participation in these processes not as representation of their firms, but as private citizens of Bad Berleburg. Yet, a distinction between these roles seems not always to be clearly drawn, as private and corporate functions might easily overlap in public perception.

I participated but I perceived it as private meeting. It makes a difference whether the minutes of the meetings say "the representative of BSW or Mr. [family name]" said something. [...] But in a small town like Bad Berleburg all of that blurs.

(Interview BSW, August 8, 2018)

Besides this local engagement, BSW and EJOT take on responsibilities in regional development processes. For instance, as a member of the steering groups of the LEADER region Wittgenstein, the regional Chamber of Commerce, and economic associations and initiatives lobbying for better regional infrastructure connections. ${ }^{1}$

One central project in Bad Berleburg in which both local Hidden Champions have been actively engaged is a newly built regional community centre integrating both touristic and social functions. ${ }^{2}$ The centre constitutes a central, strategic urban development project of Bad Berleburg. At its core, it contains a multifunctional event and meeting place where several central organisations of the town (municipal youth welfare, Wisent world, tourist office, etc.) are bundled and rooms for further associations and initiatives are available. The total investment is about $€ 2.5$ million, of which $70 \%$ was financed by federal and state funds. Through the donation of $€ 200,000$ each by BSW and EJOT, the municipality was able to co-finance its 30\% share of total project costs. Additionally, the companies contributed also to the planning process, by sharing their expertise in terms of event management and the likely specific needs of such a place. This corporate engagement is 


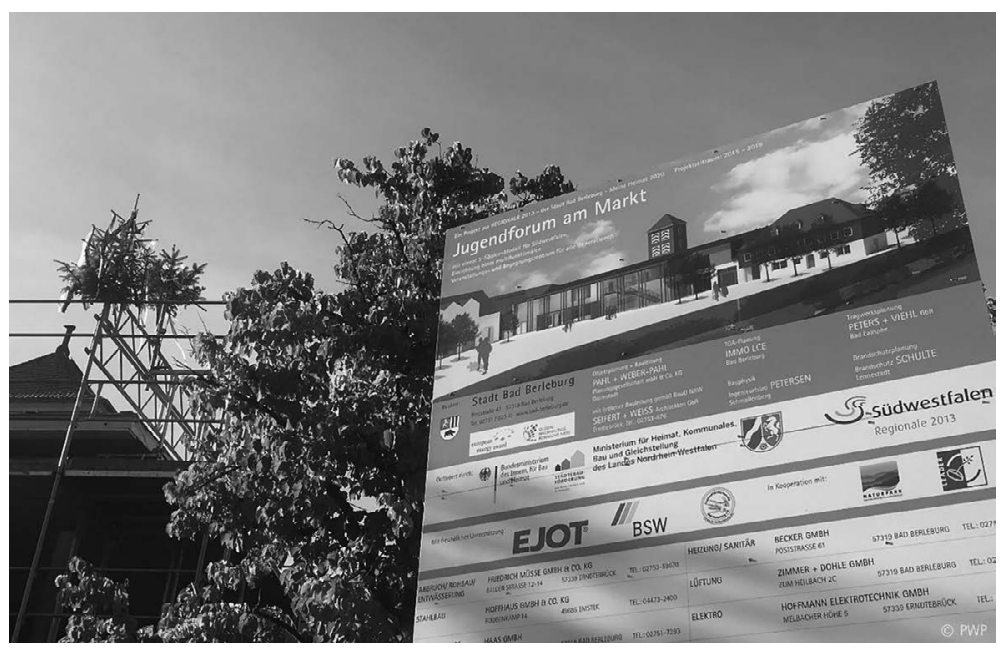

Figure 8.1 Roofing ceremony of community centre in Bad Berleburg. Source: Pahl + Weber-Pahl Planungsgesellschaft mbH \& Co. KG.

one of the reasons why the community centre is considered a "best practice example of regional engagement" (Prasse, 2018). Yet, there are also specific and firm-related motivations that guide the support. First, BSW and EJOT can use the centre as a venue for their own events - something they had lacked. Second, the centre offers dedicated space for projects and events for adolescents to increase the attractiveness of Bad Berleburg for families, an important target group for both the municipality and local firms.

I was convinced [by the project] rather quickly, because it is good for Bad Berleburg. [We get] a representative building where receptions and other events can be arranged, even bigger ones.

(Interview EJOT, August 8, 2018)

In contrast, Holmer's corporate support activities are less pronounced than those of the companies in Bad Berleburg. Both Schierling's administration and its management underline the strict distinction between municipal and entrepreneurial competencies and tasks. This understanding may be one of the reasons why long-term engagement does not play a big role in Holmer's voluntary activities, with the exception of its participation in the climate council of the municipality and its membership in the local economic association. Holmer's activities manifest in rather low-threshold activities such as project and event sponsoring. Still, the firm's management is interested in current urban development and planning processes and supports them ideationally, but it does not actively engage in strategy formation or project implementation: 
There is no strategic cooperation regarding urban development. We do not meet with the city council and jointly develop a long-term plan.

(Interview Holmer, November 06, 2018)

\section{Discussion: from corporate engagement to cooperative action}

Using the examples of three Hidden Champions in Germany, the study examines the local effects of successful operating firms located in small towns in peripheral regions. In economic terms, the three selected companies are important local players and are well embedded within their regions. The firms contribute significantly to municipal budgets, offer diverse employment opportunities, and strengthen regional value chains through strategic purchasing.

Going beyond this economic dimension, our results suggest that successful and locally embedded firms are generally willing to provide substantial (monetary and non-monetary) resources for community purposes. We find evidence of the most common activities related to CLRR, such as cultural, social, and educational matters. Therefore, we validate activities identified in previous studies as central dimensions of firm engagement, which are widely accepted and appreciated activity fields by local/regional initiatives as well as policy-makers (Lengauer \& Tödtling, 2010; Vilain, 2010). However, we find that firm engagement is driven by a set of diverse motivations that is implicitly and explicitly coupled with their own interests (see Figure 8.2). Aspects such as recruitment/retention of skilled employees and development strategies for young professionals are closely intertwined with challenges of locational attractiveness, which are of particular importance in peripheral regions.

\section{Corporate motives}

Corporate resources

secure skilled workforce, secure corporate development, ...

Infrastructural conditions

improve traffic and technical infrastructure, digitalisation, ...

Future viability of place and region secure potential of skilled workforce, maintain/develop educational offers, ...

Corportate visibility image cultivation, reputation building, ...

Attractiveness of place and region increase attractiveness of living and working environment,

"offer something" to employees, ...
Personal motives

Motivation of decision-makers citizens of small towns, bond to place and region, commitment/obligation, ...
Local and regional responsibility strengthen local/regional embeddedness and responsibility, communicate commitment to place and region, increase identification with the region, ...

Figure 8.2 Motives for CLRR activities. 
Considering family firms and non-family firms, the study allows for reflections on the specific role of family ownership for CLRR activities and to expand previous research findings (e.g., Bürcher, 2017; Lengauer \& Tödtling, 2010; Vilain, 2010). Firms generally seem to have a high level of awareness that their engagement may operate as a mechanism to maintain and increase social, cultural, and educational infrastructures and, thereby, actively and consciously shape the attractiveness of place and region. Given the particular context of small towns in peripheral regions, such soft factors are highly relevant for firms, municipalities, and civil society actors, as they constitute determining factors for wider development dynamics of both firms and small towns. Since the spatial focus of engagement is mainly on the immediate firm environments, diverse CLRR activities related to corporate giving and corporate volunteering have particularly pronounced implications for small-town development. CLRR activities, especially in the fields of corporate giving and corporate volunteering, constitute substantial supplements to the activities and investments of municipal and civil society actors and, thereby, open room for manoeuvres to shape and strengthen local and regional structures. We find that the ownership nature of the firm (family or non-family) seems not to affect the types of engagements related to corporate giving and corporate volunteering - i.e., all firms use these activities regardless the nature of their ownership.

However, the case studies provide various indications that ownership structures might affect scope and intensity of corporate engagement. Decision-makers of the family-owned Hidden Champions are particularly engaged in terms of comprehensive and strategic corporate support activities. Such comprehensive forms of engagement - e.g., steering group membership in local institutions or participation in municipal strategy processes can be partly attributed to personal motivations that emerge due to family firms' specific and individual factors as well as socio-emotional dimensions of embeddedness (Bird \& Wennberg, 2014; Campopiano et al., 2014). In this sense, engagement is driven by a sincere sense of obligation and responsibility, resulting in efforts to provide positive returns to the local community. Place related and socio-emotional attachment emerges in the motives of family firms. As decision-takers grew up and still live locally, they have more profound motivations to contribute to the development of their hometowns and to build diverse cultural and social landscapes. These specific socio-emotional motivations are less pronounced for managers in non-family firms, especially if decision-makers do not live locally or if a high fluctuation can be observed among them.

Furthermore, our study highlights the importance of adopting a procedural understanding of embeddedness (Hess, 2004; Pike et al., 2000). Events such as ownership changes may affect the degree of embeddedness, the perception of a firm's local and regional responsibility, and, consequently, the intensity of CLRR activities; more generally, it can alter the nature of ties to stakeholders (Zellweger et al., 2019). Such aspects become apparent in 
Holmer's acquisition by and long-term affiliation with an international private equity fund. During this period, both firm embeddedness and CLRR activities were substantially reduced. However, the acquisition of Holmer by a French family holding in 2013 facilitated the process of gradual (re-)embedding by defining new trustful ties with the municipality and other local actors. Unlike Holmer, BSW and EJOT reflect a high degree of continuity as both firms are third-generation family firms. We interpret continuity as a constantly ongoing embedding process, which facilitates the emergence of shared mindsets and high trust levels (Dörhöfer et al., 2011) that result in institutionalised engagement and joint development of projects and initiatives along the lines of corporate support.

These aspects further illustrate the (potential) role of family involvement in firms, which seems to point to a specific corporate culture, including intentions to build diverse connections with community stakeholders (Campopiano et al., 2014; Zellweger et al., 2019) - even if family involvement relates to the macro holding-level. On the one hand, these results highlight the diverse and distinct local and regional values of maintained-family ownership of medium-sized firms such as Hidden Champions. On the other hand, our results pose the question of how these values can be effectively secured - e.g., as part of (family-external) company succession or (international) merger and acquisition processes.

Despite their generally positive attitude towards corporate engagement, all firms emphasise that the level and intensity depends on their (current) economic success, which highlights the processual nature of corporate engagement itself (Gallo, 2004; Lengauer \& Tödtling, 2010). The latter aspect also has an important implication for municipal and civil society actors, who must avoid being dependent on voluntary sponsoring and support related CLRR activities in case firms restrain their efforts.

\section{Contributions}

This chapter offers useful perspectives for policy-makers in the context of small-town development. As firms' and municipalities' goals substantially overlap, opportunities for cooperative action emerge. In this context, the identification of joint goals between firms, municipalities, and civil society actors is an essential driver of successful cooperation and steering development processes. Corporate engagement provides a specific development resource to activate and strategically exploit - especially for peripherally located municipalities and small towns where the maintenance of attractive living environments faces complex and specific challenges, compared to larger agglomerations. To mobilise these potentials and to tap new/additional resources (financial, time, ideas, etc.) municipalities need to find ways to channel the obviously existing willingness of firms to engage in local and regional matters. The identification and implementation of concrete joint projects that involve private, public, and civil society actors (like the 
community centre in Bad Berleburg) offer promising mechanisms to strategically engage firms based on common goals, envisaged outcomes, agreed responsibilities and resources, and clear time frames.

Thereby, firms can be actively and strategically involved in local development processes, to create mutually accepted outcomes. As we observe in our research, family firms are comprehensively engaged in local development processes. Besides strategically organising the corporate support activities of family firms, a central challenge for municipal actors can be seen in the activation of non-family firms or subsidiaries of larger companies to also engage in these processes. Their purposive activation could mobilise additional resources and facilitate the emergence of distributed and multi-actor CLRR development structures involving both family and non-family firms. When it comes to building such distributed structures, our study highlights that small towns might operate as particularly effective environments: the number of potential firms to be targeted is limited, decision-makers within firms are usually not anonymous and are accessible, and communicative distances are rather small, i.e., associated issues and activities can be discussed quickly via formal and informal channels.

\section{Acknowledgments}

The empirical part of this chapter was conducted as part of the project "Hidden Champions - Stabilisierungs- und Entwicklungsfaktoren von Kleinstädten in peripheren Lagen" [Hidden Champions - stabilisation factors and development drivers of small towns in peripheral locations], funded by the Federal Institute for Research on Building, Urban Affairs and Spatial Development (BBSR). We thank our interviewees for their time and interest in the project; Thilo Lang, Lukas Vonnahme, and Lars Porsche for constructive discussions; and the book editors for helpful feedback on earlier stages of this chapter.

\section{Notes}

1 EJOT's CEO is founding member of the initiative 'Route 57' which lobbies for improving infrastructural connections of the region.

2 The German project title of the centre "Bürgerhaus am Markt".

\section{References}

Aparicio, G., Basco, R., Iturralde, T., \& Maseda, A. (2017). An exploratory study of firm goals in the context of family firms: An institutional logics perspective. Journal of Family Business Strategy, 8(3), 157-169.

ARL - Academy for Spatial Research and Planning. (2019). Small Town Research in Germany - Status Quo and Recommendations. (Report No. 114). Hannover: ARL.

Basco, R. (2015). Family business and regional development-A theoretical model of regional familiness, Journal of Family Business Strategy, 4, 259-271. 
Baù, M., Block, J., Discua Cruz, A., \& Naldi, L. (2017). Locality and internationalization of family firms. Entrepreneurship \& Regional Development, 29, 570-574.

Baù, M., Chirico, F., Pittino, D., Backman, M., \& Klaesson, J. (2019). Roots to grow: Family firms and local embeddedness in rural and urban contexts. Entrepreneurship Theory and Practice, 2, 360-385.

Bell, D., \& Jayne, M. (2009). Small cities? Towards a research agenda. International Journal of Urban and Regional Research, 3, 683-699.

Bird, M., \& Wennberg, K. (2014). Regional influences on the prevalence of family versus non-family start-ups. Journal of Business Venturing, 3, 421-436.

Bürcher, S. (2017). Regional engagement of locally anchored firms and its influence on socio-economic development in two peripheral regions over time. Entrepreneurship \& Regional Development, 7-8, 692-714.

Campopiano, G., De Massis, A., \& Chirico, F. (2014). Firm philanthropy in smalland medium-sized family firms: The effects of family involvement in ownership and management. Family Business Review, 3, 244-258.

Chrisman, J.-J., Chua, J.-H., Pearson, A.-W., \& Barnett, T. (2012). Family involvement, family influence, and family-centered non-economic goals in small firms. Entrepreneurship Theory and Practice, 2, 267-293.

Clifton, N., Gärtner, S., \& Rehfeld, D. (2011). Companies, cultures, and the region: Interactions and outcomes. European Planning Studies, 11, 1857-1864.

Deephouse, D.-L., \& Jaskiewicz, P. (2013). Do family firms have better reputations than non-family firms? An integration of socioemotional wealth and social identity theories. Journal of Management Studies, 3, 337-360.

Dequech, D. (2003). Cognitive and cultural embeddedness: Combining institutional economics and economic sociology. Journal of Economic Issues, 2, 461-470.

Deutscher Städtetag. (2013). Integrierte Stadtentwicklungsplanung und Stadtentwicklungsmanagement - Strategien und Instrumente nachhaltiger Stadtentwicklung. [Integrated Urban Development Planning and Management - Strategies and Instruments for Sustainable Urban Development]. Berlin, Köln: Association of German Cities.

Dörhöfer, S., Minnig, C., Pekruhl, U., \& Prud'homme van Reine, P. (2011). Contrasting the footloose company: Social capital, organizational fields and culture. European Planning Studies, 11, 1951-1972.

Gallo, M.-A. (2004). The family business and its social responsibilities. Family Business Review, 2, 135-149.

Granovetter, M. (1973). The strength of weak ties. American Journal of Sociology, $6,1360-1380$.

Hess, M. (2004). "Spatial" relationships? Towards a reconceptualization of embeddedness. Progress in Human Geography, 2, 165-186.

Hohn, U., Kleine-König, C., \& Schiek, M. (2014). Corporate local and regional responsibility: Gesellschaftliche Verantwortung von Unternehmen für Quartier, Stadt und Region [Corporate local and regional responsibility: Corporate responsibility for neighbourhood, city and region], Berichte. Geographie und Landeskunde, 2, 123-152.

Kiese, M., \& Schiek, M. (2016). Unternehmerische Verantwortung in der Stadt- und Regionalentwicklung [Corporate responsibility in urban and regional development], Standort, 40.

Lang, T., Görmar, F., Graffenberger, M., \& Vonnahme, L. (2019). Hidden Champions und Stadtentwicklung. Die wirtschaftliche und gesellschaftliche Bedeutung 
innovativer Unternehmen für Kleinstädte in peripherer Lage [Hidden Champions and Urban Development: The Economic and Societal Importance of Innovative Companies for Small Towns in a Peripheral Location]. Bonn: Federal Institute for Research on Building, Urban Affairs and Spatial Development (BBSR).

Lengauer, L., \& Tödtling, F. (2010). Regional Embeddedness and Corporate Regional Engagement: Evidence from three industries in the Austrian region of Styria, Paper presented at the 8th European Urban \& Regional Studies Conference, Vienna.

Pike, A., Lagendijk, A., \& Vale, M. (2000). Critical reflections on "embeddedness" in economic geography: the case of labour market governance and training in the automotive industry in the North East region of England. In A. Giunta, A. Lagendijk, \& A. Pike (Eds.), Restructuring Industry and Territory: The Experience of Europe's Regions (pp. 59-82). London: TSO.

Prasse, B. (2018, September 30). Jugendforum am Markt in Bad Berleburg feiert Richtfest [Roofing ceremony of the community centre]. Westfalenpost. Retrieved from: www.wp.de/staedte/wittgenstein/jugendforum-am-markt-in-bad-berleburg-f eiert-richtfest-id215452067.html.

Stiftung Familienunternehmen. (2019). Die volkswirtschaftliche Bedeutung der Familienunternehmen [The Economic Importance of Family Businesses], München: Stiftung Familienunternehmen.

Stough, R., Welter, F., Block, J., Wennberg, K., \& Basco, R. (2015). Family business and regional science: "Bridging the gap". Journal of Family Business Strategy, 4, 208-218.

Vilain, M. (2010). „Meine Firma, meine Mitarbeiter, meine Heimat.“ Merkmale unternehmerischen Engagements im deutschen Mittelstand ["My company, my employees, my hometown" Characteristics of corporate engagement in the German Mittelstand]. In S. Braun (Ed.), Gesellschaftliches Engagement von Unternehmen: Der deutsche Weg im internationalen Kontext. (pp. 106-146). Wiesbaden: VS Verlag für Sozialwissenschaften.

Vonnahme, L., Graffenberger, M., Görmar, F., \& Lang, T. (2018). Kaum beachtet, gemeinsam stark: Versteckte Potenziale von Kleinstädten mit Hidden Champions [Hardly noticed, strong together: Hidden potentials of small towns with Hidden Champions]. In: Informationen zur Raumentwicklung, 6, 38-49. Retrieved from https://www.bbsr.bund.de/BBSR/DE/Veroeffentlichungen/IzR/2018/6/Inhalt/downloads/hidden-champions.pdf?__blob=publicationFile\&v=2.

Zellweger, T.-M., Chrisman, J.-J., Chua, J.-H., \& Steier, L.-P. (2019). Social structures, social relationships, and family firms. Entrepreneurship Theory and Practice, 2, 207-223. 